\title{
Carbon, Nitrogen, and Orthophosphate Leaching from Soil under Single- and Mixed-species Landscapes
}

\author{
Tim R. Pannkuk ${ }^{1}$ \\ Department of Agricultural Sciences, P.O. Box 2088, Sam Houston State \\ University, Huntsville, TX 77340
}

Jacqueline A. Aitkenhead-Peterson

Department of Soil and Crop Sciences, Texas A\&M University, College Station, TX 77840

\section{Kurt Steinke \\ Department of Crop and Soil Sciences, Michigan State University, East Lansing, MI 48824}

\section{James C. Thomas, David R. Chalmers, and Richard H. White Department of Soil and Crop Sciences, Texas A\&M University, College Station, TX 77840}

Additional index words. turf, landscape, leachate, dissolved organic carbon, bicarbonate, nitrogen

\begin{abstract}
Effective landscape management practices in urban landscapes must include an awareness of nutrient removal from soil caused by leaching, and these practices should be those least damaging to freshwaters. Annual mean dissolved organic carbon (DOC), dissolved organic nitrogen (DON), nitrate-N, ammonium-N, soluble phosphate, and bicarbonate concentrations and fluxes were quantified in leachate from landscapes planted with different urban horticultural types. Plot vegetation consisted of either a single species or mixed species. The experiment was conducted at two sites in Texas with significantly different irrigation water chemistry. At the two sites, plant species had a significant effect on $\mathrm{PO}_{4}{ }^{3-}-\mathrm{P}$ flux, and irrigation chemistry had a significant effect on all nutrient fluxes. There was an interaction between plant species and irrigation chemistry for $\mathrm{PO}_{4}{ }^{3-}-\mathrm{P}$ flux $(P<0.05)$ only. The relationship between bicarbonate and DOC flux at sites was stronger and significant $(0.92 ; P<0.05)$ at the site irrigated with $\mathrm{Na}-\mathrm{HCO}_{3}$ municipal tap water than at the site irrigated with $\mathrm{Ca}-\mathrm{HCO}_{3}$ municipal tap water $\left(R^{2}=\right.$ $0.76, P=0.05)$. Type of irrigation water chemistry may result in lower plant water uptake resulting in increased nutrients lost to leachate.
\end{abstract}

Excessive losses of nitrogen $(\mathrm{N})$, orthophosphate $(\mathrm{P})$, and DOC from soil by leaching is indicative of breaks in their respective nutrient cycles. Losses of these nutrients are typically caused by management practices or natural disturbances in the local environment. For example, soil disturbance will cause excess nitrate to move out of the soil matrix because aerated soil induces nitrification; movement of excess orthophosphate is generally the result of

\footnotetext{
Received for publication 22 July 2011. Accepted for publication 22 Sept. 2011.

Site construction and lysimeter collection were supported by the Soil and Crop Science Department, Texas A\&M University, Turfgrass Producers of Texas and Texas Nursery and Landscape Association. The land at the San Antonio research site was provided by the San Antonio Water System. Leachate analysis was supported by the Texas AgriLife Research Hatch Project TEX09194 (J.A. Aitkenhead-Peterson).

We thank Ms. Nina Stanley for help with leachate analysis.

${ }^{1}$ To whom reprint requests should be addressed; e-mail pannkuk@shsu.edu.
}

overapplication of phosphate fertilizer to a soil that is already saturated with $\mathrm{P}$ and DOC losses typically occur when manures or biosolids are applied as fertilizer (Schnell et al., 2010). Nitrogen and $\mathrm{P}$ movement from terrestrial to aquatic ecosystems may contribute to surface water and estuarine impairment such as eutrophication (Paerl, 2009). Organic carbon may also contribute to water quality problems by increasing biological oxygen demand in surface waters (Faulkner et al., 2000; McConnell, 1980), and further it is implicated in the formation of trihalomethanes if the surface water is removed and chlorinated for drinking water supply (Siddiqui et al., 1997).

Effective landscape management practices in urban landscapes must include an awareness of nutrient removal from soil caused by leaching. For example, one way of minimizing groundwater contamination by nitrate is by maintaining a vigorous turfgrass cover (Jiang et al., 2000). Landscape plants not only provide aesthetic appeal and improve groundwater recharge in urban ecosystems, but they also reduce soil erosion, which can impair surface waters (Beard and Green, 1994). In addition, irrigated, landscaped areas within the built landscape can increase property values (Vickers, 2001).

The use of alternative plants in the landscape is increasingly being used to reduce environmental impacts and decrease water use (City of Albuquerque, 2006; Hipp et al., 1993; Sacamano and Jones, 1975; Xeriscape Colorado, 2005). As a way to reduce $\mathrm{N}$ leaching, the University of Florida Cooperative Extension Service initiated an effort in the 1990 s to promote alternative landscapes that included woody and herbaceous plants; this practice would minimize turfgrass area (Garner et al., 1996). However, when Erickson et al. $(2001,2005)$ examined differences in nitrate and $\mathrm{P}$ leaching related to species composition during a study in south Florida, they observed reduced nitrate and $\mathrm{P}$ leaching from areas planted with st. augustinegrass [Stenotaphrum secundatum (Walt.) Kuntze] compared with those areas planted with mixed-species ornamental plants.

The effect of irrigation water chemistry on DOC and DON solubility and transport in an urban context has only received modest attention (e.g., Aitkenhead-Peterson et al., 2009, 2011a; Holgate et al., 2011). AitkenheadPeterson et al. (2009) suggested that irrigating turfgrass in urban open areas with municipal tap water high in sodium may induce sodic soil conditions in urban watersheds resulting in elevated average annual DOC concentrations. Leaching of DOC and DON from soil under three sedum plant species typically used for green roofs was in part attributed to irrigation water high in sodium, which, in combination with a moderate to high $\mathrm{pH}$ and a well-buffered soil, likely solubilized humic acids leading to a high bulk DOC loss (AitkenheadPeterson et al., 2011a). Holgate et al. (2011) reported minimal losses of DOC, N, and orthophosphate-P from soils under perennial ryegrass irrigated with harvested rain water compared with soils irrigated with municipal tap or gray water.

Leaching to surface waters tends to be linked to Jenny's (1941) soil-forming factors, which have more recently been coined "state factors" (Aitkenhead-Peterson et al., 2005, 2011b; Perakis and Hedin, 2007). One of these state factors is vegetation and its associated microbes; thus, it could feasibly be expected that different landscaping vegetation species may have some control on reducing or increasing leaching such as those differences reported by Erickson et al. $(2001,2005)$ for st. augustinegrass and ornamental landscape species in Florida.

The major objectives of this study were to examine 1) which landscape plant species might reduce carbon (C), N, and P leaching; and 2) the effect of irrigation water chemistry on $\mathrm{C}, \mathrm{N}$, and $\mathrm{P}$ released to leachate. We hypothesized that in a managed urban system, different vegetation types would influence DOC and DON leaching and that irrigation water chemistry would contribute to differences in all nutrient leaching fluxes. We expected that irrigation water high in sodium rather 
than calcium would increase DOC fluxes from all vegetation types.

\section{Materials and Methods}

Site description. Our study was conducted at two sites, the Texas A\&M University Turfgrass Field Laboratory in College Station, TX (CS) and at a site adjacent to the San Antonio Water System Leon Creek Waste Water Treatment Facility in San Antonio, TX (SA). During the study period, CS had $972 \mathrm{~mm}$ annual precipitation, $69 \% \pm 10 \%$ humidity (Table 1 ), and evapotranspiration $\left(\mathrm{ET}_{\mathrm{o}}\right)$ of $1430 \mathrm{~mm}$ (Pannkuk et al., 2010), whereas SA was slightly drier with an annual precipitation of $870 \mathrm{~mm}$, $67 \% \pm 13 \%$ humidity (Table 1 ) and an $\mathrm{ET}_{\mathrm{o}}$ of $1522 \mathrm{~mm}$ (Pannkuk et al., 2010). Samples of water used for irrigation were collected from both sites on several occasions in 2008. Irrigation water for CS was a municipal tap water derived from 900-m groundwater wells in the Carrizo-Wilcox aquifer (Aitkenhead-Peterson et al., 2011b). Irrigation water for SA was a municipal tap water derived from the Edwards and Trinity aquifers. The chemistry of the two irrigation waters was very different; CS water, a $\mathrm{Na}-\mathrm{HCO}_{3}$-type water had high salinity and sodicity hazards, whereas the SA water had a $\mathrm{Ca}-\mathrm{HCO}_{3}$-type water with a medium salinity and low sodicity hazard (Table 2). Although there was no significant difference in climatic conditions between the two sites although they were $272 \mathrm{~km}$ apart, there were significant differences in the ion content of the irrigation water, which was likely the result of groundwater well depth and aquifer geology (Table 2).

Lysimeter construction. A detailed description of the lysimeter construction can be found in Pannkuk et al. (2010). Briefly, lysimeters were made from 1.136-L oval stock tanks (R.G. Applegate Steel Co., Saratoga, IN) that are $2.43 \mathrm{~m}$ long $\times 1.02 \mathrm{~m}$ wide $\times 0.68 \mathrm{~m}$ deep. Tanks were placed in-ground on a smooth level surface; the tank tops were $5 \mathrm{~cm}$ beneath the surface grade. The space between the individual lysimeters in the field was 30.5 $\mathrm{cm}$. Tanks were filled with $1 \mathrm{~cm}$ diameter gravel to a depth of $5.1 \mathrm{~cm}$. An evacuation pipe system was embedded in the gravel layer to allow vacuum removal of leachate. The end of each lateral pipe was permanently

Table 1. Climatic conditions and irrigation inputs at College Station (CS) and San Antionio (SA) during the leachate collection period of May 2007 to Apr. 2008.

\begin{tabular}{lccccc}
\hline Site & $\begin{array}{c}\text { Temperature } \\
\left({ }^{\circ} \mathrm{C}\right)\end{array}$ & $\begin{array}{c}\text { Humidity } \\
(\%)\end{array}$ & $\begin{array}{c}\text { Wind speed } \\
(\mathrm{mph})\end{array}$ & $\begin{array}{c}\text { Precipitation } \\
(\mathrm{mm})\end{array}$ & $\begin{array}{c}\text { Irrigation } \\
(\mathrm{mm})\end{array}$ \\
\hline $\mathrm{CS}$ & $21 \pm 10$ & $69 \pm 10$ & $8 \pm 3$ & 972 & 529 \\
SA & $21 \pm 9$ & $67 \pm 13$ & $8 \pm 3$ & 870 & 900 \\
\hline
\end{tabular}

Means \pm SD.

capped. Holes ( $3 \mathrm{~mm}$ diameter) were drilled in the bottom of each lateral line at $10-\mathrm{cm}$ spacing to allow water to enter the pipes. Soil $(1.27 \mathrm{~cm})$ Rader fine sandy loam soil series (fine-loamy, mixed, semiactive, thermic Aquic Paleustalfs) derived from an unimproved, unfertilized pasture. Approximately 15 to $20 \mathrm{~cm}$ of loose soil was added in lifts and manually compacted with a hand tamper to a finished depth of $10 \mathrm{~cm}$. This was repeated with each lift of soil until lysimeters were filled to ground level. The soil had a dry bulk density of $1.52 \mathrm{~g} \cdot \mathrm{cm}^{-3}\left( \pm 0.02 \mathrm{~g} \cdot \mathrm{cm}^{-3}\right)$. Lysimeters for the SA location were built in $\mathrm{CS}$, transported to SA, and installed in-ground. A two-zone in-ground automatic irrigation system was used at each site for lysimeter irrigation.

Irrigation spray heads (Hunter PGJ Series, San Marcos, CA) were installed at 3.65-m triangulated spacing. A water meter was installed in each zone to allow measurement of total applied water. Data from weather stations within $250 \mathrm{~m}$ of each site were used to calculate reference evapotranspiration using the modified Penman-Monteith equation (FAO, 1998). Irrigation volume (IV) was adjusted every 2 to 3 weeks to replace $100 \%$ of calculated reference $\mathrm{ET}_{\mathrm{o}}$ minus rainfall (R) (Eq. 1). Plots were irrigated with an appropriate irrigation volume as needed based on $\mathrm{ET}_{\mathrm{o}}$ minus rainfall (Fig. 1).

$$
\mathrm{IV}=\mathrm{ET}-\mathrm{R}
$$

Treatments. To examine the effect of vegetation species on biogeochemical leaching, we selected plant treatments that were typically used in urban landscaping in our region. Plant treatments were arranged in a randomized complete block design with three replicates for each plant treatment and were randomly assigned to the lysimeters within each block. Treatments were: 1) st. augustinegrass [Stenotaphrum secundatum (Walt.) Kuntze.] 100\% cover; 2) shumard red oak (Quercus shumardii Buckl.) tree alone with bare soil; 3) native grasses-little bluestem [Schizachyrium scoparium (Michx.) capillaries (Lam.) Trin.]; 4) st. augustinegrass [Stenotaphrum secundatum (Walt.) Kuntze.] used in each of the lysimeters was a sieved Nash] and pink muhlygrass [Muhlenbergia

Table 2. Concentrations of the major chemical components of irrigation water collected over the course of the study.

\begin{tabular}{|c|c|c|c|c|c|c|c|c|c|c|c|}
\hline \multirow[b]{2}{*}{ Site } & \multirow[b]{2}{*}{$\mathrm{N}$} & \multirow[b]{2}{*}{$\mathrm{pH}$} & \multirow{2}{*}{$\begin{array}{c}\mathrm{EC} \\
\left(\mu \mathrm{S} \cdot \mathrm{cm}^{-1}\right)\end{array}$} & $\mathrm{PO}_{4}{ }^{3-}-\mathrm{P}$ & $\mathrm{K}^{+}$ & $\mathrm{Ca}^{2+}$ & $\mathrm{Mg}^{2+}$ & $\mathrm{SO}_{4}^{2-}$ & $\mathrm{HCO}_{3}^{-}$ & $\mathrm{Na}^{+}$ & SAR \\
\hline & & & & \multicolumn{8}{|c|}{ 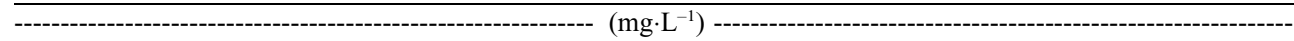 } \\
\hline$\overline{\mathrm{CS}}$ & 20 & ${ }^{\mathrm{a}} 8.4 \pm 0.1^{\mathrm{z}}$ & $648 \pm 35$ & $0.2 \pm 0.1$ & $3.0 \pm 2.6$ & ${ }^{\mathrm{a}} 3.0 \pm 0.6$ & ${ }^{\mathrm{a}} 0.4 \pm 0.1$ & ${ }^{\mathrm{a}} 0.6 \pm 0.1$ & a346 \pm 31 & ${ }^{\mathrm{a}} 206 \pm 24.8$ & ${ }^{a} 34 \pm 5$ \\
\hline SA & 6 & b7. $6 \pm 0.3$ & $560 \pm 14$ & $0.02 \pm 0.02$ & $6.1 \pm 2.0$ & b $36.8 \pm 1.7$ & ${ }^{\mathrm{b}} 15.7 \pm 1.8$ & ${ }^{\mathrm{b}} 25.1 \pm 15.5$ & ${ }^{\mathrm{b}} 179 \pm 11$ & ${ }^{\mathrm{b}} 18.5 \pm 2.2$ & ${ }^{\mathrm{b}} 0.6 \pm 0.1$ \\
\hline
\end{tabular}

${ }^{\mathrm{z}}$ Any two means within a row not followed by the same letter are significantly different at $P \leq 0.05$.

$\mathrm{N}=$ nitrogen; $\mathrm{EC}=$ electrical conductivity; $\mathrm{SAR}=$ sodium adsorption ratio; $\mathrm{CS}=$ College $\mathrm{Station}, \mathrm{TX} ; \mathrm{SA}=\mathrm{San}$ Antonio, TX . plus one shumard red oak (Quercus shumardii Buckl.); 5) native grasses plus one shumard red oak; and 6) 'Tifway' bermudagrass ( $\mathrm{Cyn}$ odon dactylon $\times C$. transvaalensis, BurttDavy) $100 \%$ cover.

Treatment 6 was used at the CS site only. Plant installation occurred on 19 Dec. 2006 and 20 Dec. 2006 for the SA and CS locations, respectively. To avoid disturbing soil moisture sensors and their cables in the lysimeters, container-grown $(11.4 \mathrm{~L})$ shumard red oak trees were planted in the center of the lysimeters. Native grasses were spaced equidistant across the lysimeter. st. augustinegrass and 'Tifway' bermudagrass (All Seasons Turfgrass Inc., Brookshire, TX) treatments were planted with sod grown on a Katy fine-sandy loam series (fine-loamy, siliceous, thermic Aquic Paleudalf). Native treatments received nine field-grown (3-L root ball) individual little bluestem and two container-grown (5.7$\mathrm{L}$ root ball) individual pink muhlygrass. The tree + native treatment received eight little bluestems and two pink muhlygrasses.

Site management. St. augustinegrass was mowed at 5- to 7.6-cm cutting height every 2 to 4 weeks. Mowing heights are typically higher during the summer months to reduce plant stress. The bluestem and muhlygrass (native and tree + native treatments) were trimmed with handheld clippers to 15 to 18 $\mathrm{cm}$ each December. Clippings were returned to their respective plots. The soil in the st. augustinegrass treatment was sampled ( 0 - to $15-\mathrm{cm}$ depth) for laboratory analysis twice during the experimental period and based on this soil analysis, a balanced fertilizer was added to all treatments during 2007 and 2008. Nitrogen at a rate of $48.8 \mathrm{~kg} \cdot \mathrm{ha}^{-1}$ and $\mathrm{P}$ at a rate of $17 \mathrm{~kg} \cdot \mathrm{ha}^{-1}$ were applied three times a year. Fertilizer was broadcast uniformly across plots in all treatments in spring, summer, and fall. The $\mathrm{N}$ source was $50 \%$ slowrelease methylene urea. Soil test results for $\mathrm{P}$ were $15 \mathrm{ppm}$ at the beginning of the experiment and 23 ppm in May 2008. Soil organic matter in May 2008 was $0.78 \%$ and $0.52 \%$ in CS and SA, respectively. Although fertilizer requirements are different for different vegetation species, we elected to apply the same balanced fertilizer to all plant treatments at both sites to avoid confounding nutrient fluxes.

Azoxystrobin [methyl 2-2-6-(2-cyanophenoxy) pyrimidin-4-yloxy-phenyl-3-methoxyacrylate] fungicide was applied in Mar. 2007 at $9.8 \mathrm{~g} \cdot \mathrm{m}^{-2}$ for brown patch (Rhizoctonia solani) control to all treatments containing turfgrass. Fipronil \{5-amino-1-[2,6-dichloro-4-(trifluoromethyl)phenyl]-4-[(1R,S)-(trifluoromethyl)sulfinyl]-1H-pyrazole-3-carbonitrile $\}$ insecticide was applied at $9.8 \mathrm{~g} \cdot \mathrm{m}^{-2}$ in 2007 and 2008 

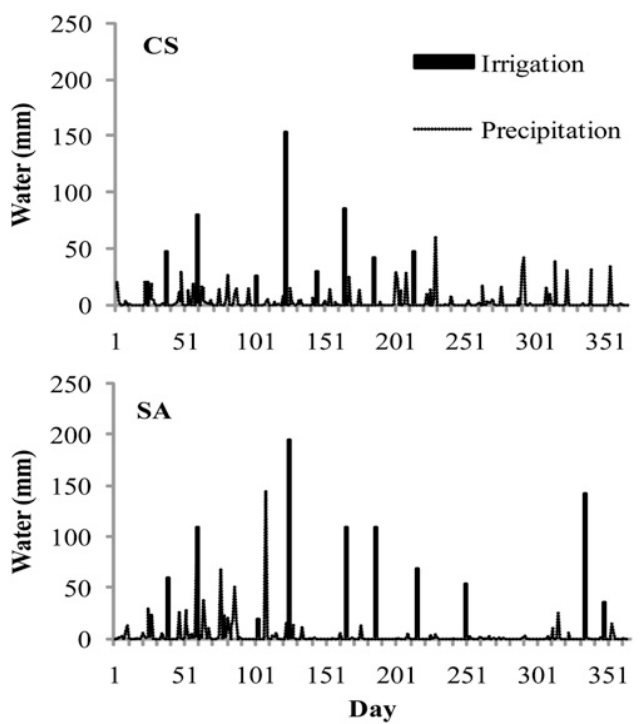

Fig. 1. Irrigation and precipitation inputs to plots between May 2007 and Apr. 2008.

for red imported fire ant control in all plots. All shumard red oak trees received triforine [N,N-bis-(1 formamido-2,2,2-trichloroethyl)piperazine] fungicide at budbreak in Mar. 2008 to prevent symptoms of anthracnose. A $1-\mathrm{m}$ perimeter around the block of lysimeters was treated monthly with glyphosate [2-(phosphonomethylamino) acetic acid] herbicide at both sites.

Leachate was removed from the lysimeters every 2 to 4 weeks to avoid saturation of the gravel layer. A 0.75 -hp vacuum pump (Gast, Model 1023 V2G583X) with a tension of 116 mbar at the pump and a $1.5-\mathrm{cm}$ i.d. polyethylene hose was attached to a calibrated 20-L glass carboy. A second polyethylene hose was attached to the carboy and the leachate removal line of the lysimeter. At each lysimeter, the pump was powered until the lysimeter stopped yielding leachate $(\approx 12 \mathrm{~min})$. Leachate volume was recorded, and a $200-\mathrm{mL}$ subsample was retained in acid-washed, leachaterinsed high-density polyethylene sample bottles. Samples were frozen until analysis. Leachate samples were collected from Jan. 2007 through Aug. 2008. However, to ensure that soil solution chemistry had reached equilibrium, and to avoid the disturbance effects of lysimeter construction, only leachate samples collected between May 2007 and Apr. 2008 were used for this study. Not every lysimeter contained leachate at each sampling event and samples collected from each plot ranged from $n=1$ to $\mathrm{n}=13$ at $\mathrm{CS}$ and $\mathrm{n}=4$ to $\mathrm{n}=10$ at SA.

Chemical analysis. Electrical conductivity (EC) and $\mathrm{pH}$ were measured on unfiltered samples. Samples for chemical analysis were filtered through ashed $\left(500{ }^{\circ} \mathrm{C}\right.$ for $\left.4 \mathrm{~h}\right)$ Whatman GF/F (nominal pore size $0.7 \mu \mathrm{m}$ ) filters. Dissolved organic carbon and total dissolved N (TDN) were measured with hightemperature Pt-catalyzed combustion using a Shimadzu TOC- $V_{\mathrm{CSH}}$ and a Shimadzu total measuring unit (TNM-1). DOC was measured as non-purgeable carbon using USEPA method 415.1, which entails acidifying $(2 \mathrm{~N} \mathrm{HCl})$ the sample and sparging for 4 min with $\mathrm{C}$-free air. Ammonium-N was analyzed using the phenate hypochlorite method with sodium nitroprussideenhancement (USEPA method 350.1), and nitrate-N was analyzed using $\mathrm{Cd}-\mathrm{Cu}$ reduction (USEPA method 353.3). Alkalinity was quantified using methyl orange (USEPA method 310.2). Alkalinity was calculated to be in the form of bicarbonate (AqQA; Rockware, Golden, CO). Soluble-P was quantified asorthophosphate-P using the ammonium molybdate method (USEPA 365.1). All colorimetric methods were performed with a Westco Scientific Smartchem Discrete Analyzer. Dissolved organic $\mathrm{N}$ is the product of TDN $\left(\mathrm{NH}_{4}{ }^{+}-\mathrm{N}+\mathrm{NO}_{3}{ }^{-}-\mathrm{N}\right)$. NIST traceable standards and control standards were run every 12 th sample for all analyses. If the percentage coefficient of variance between replicates was greater than $5 \%$, the sample was re-analyzed. Typically, the percent $\mathrm{CV}$ of replicate samples was less than $1 \%$ for colorimetric analysis and less than 5\% for DOC and TDN analyses.

Statistical analysis. Because of the significant difference in irrigation water chemistry but not climatic conditions between the two sites, irrigation water was considered a treatment. Hence, the experimental design included two irrigation water chemistries and five plant treatments, which were both used as fixed effects. Our experimental design was intended to test the hypothesis that irrigation water chemistry influences nutrient leaching from urban landscapes. By including grasstree combinations and single species, we also tested the hypothesis that vegetation type would influence nutrient leaching and that interaction effects between irrigation chemistry and landscape vegetation on nutrient leaching would occur.

Concentrations of each nutrient were tested for normal distribution and were transformed if needed before statistical analysis. Results are presented as untransformed data. Nutrient flux for each leachate constituent analyzed was calculated as the product of nutrient concentration and volume of leachate. The flux during each collection was summed to provide an annual flux per square meter. One of the lysimeters under the bermudagrass and native grass treatments produced only one sample over the year, and one of the lysimeters under the tree + native treatment produced two samples over the year; therefore, these were removed from all analyses to avoid bias on fluxes and concentrations.

Proc GLM in SAS Version 9.1 (SAS Institute, 2003) was used for the statistical analysis of nutrient concentrations and fluxes, $\mathrm{pH}$, and EC. A Univariate analysis of variance (ANOVA) with two factors, irrigation and plant species, was used to determine the effect of irrigation and plant species factors and interactions between factors on leachate nutrient concentrations and fluxes. For each individual site, a one-way ANOVA was applied to the leachate nutrient concentrations to test the effect of plant treatment on nutrient concentrations and fluxes followed by a post hoc Tukey test to determine significant differences among species. A paired two-tailed sample $t$ test (assuming equal variance) was applied to the irrigation data on paired plant species to test the effect of irrigation water quality on leachate concentrations and flux. Effects were considered statistically significant at $P \leq 0.05$. Regression analysis was used on the DOC and bicarbonate flux data to test prior findings that DOC and bicarbonate are significantly related.

\section{Results}

Mean annual leachate concentrations. There was a significant effect of irrigation water chemistry on leachate volume, $\mathrm{pH}, \mathrm{EC}$, and all nutrient concentrations with the exception of DOC, ammonium, and bicarbonate (Table 3). We also observed a significant effect of plant species on $\mathrm{pH}, \mathrm{EC}$, nitrate-N, orthophosphate-P, and the DON:TDN ratio (Table 3). An interaction between irrigation and plant species on leachate volume, DOC, nitrate-N, orthophosphate-P, bicarbonate concentrations, and the DOC:DON ratio was also observed (Table 3 ).

Effect of plant treatment on leachate chemistry. Within each sites, plant treatment had no significant effect on $\mathrm{pH}, \mathrm{EC}, \mathrm{DOC}$, $\mathrm{NH}_{4}{ }^{+}-\mathrm{N}, \mathrm{PO}_{4}{ }^{3-}-\mathrm{P}$ or $\mathrm{HCO}_{3}{ }^{-}$concentrations but had a significant effect on DON and $\mathrm{NO}_{3}{ }^{-}-\mathrm{N}$ concentrations at CS (Table 4). At $\mathrm{CS}$, mean annual DON concentration was significantly higher under the tree + native treatment compared with the bermudagrass treatment but was not significantly higher than the other treatments. Nitrate-N concentration was significantly higher in leachate under the tree + native treatment relative to concentrations leached from the single tree, bermudagrass, and st. augustinegrass treatments (Table 4). At the SA site, we observed no effect of plant species on leachate concentrations.

Effect of irrigation chemistry on leachate concentrations. All treatments at SA, with the exception of the native treatment, had significantly higher $\mathrm{pH}$ compared with CS. EC was significantly higher at CS than at SA in 
leachate under the st. augustinegrass and tree + st. augustinegrass treatments. Dissolved organic $\mathrm{C}$ concentration was significantly higher in leachate under the tree treatment at SA compared with the tree treatment at CS. Dissolved organic N concentration was significantly higher under st. augustinegrass at CS relative to SA (Table 4). The tree treatment at SA had significantly higher $\mathrm{NO}_{3}{ }^{-}-\mathrm{N}$ concentration relative to the tree treatment at CS (Table 4). With the exception of st. augustinegrass, all plant treatments at SA had significantly higher $\mathrm{PO}_{4}{ }^{3-}-\mathrm{P}$ concentrations compared with those found at CS (Table 4).

Leachate volume. Mean annual leachate volumes collected from under native grass and tree + native grass were significantly different between CS and SA (Table 4). Mean annual leachate volume collected from CS under native grass and tree + native grass was $17.9 \pm 8.4$ and $19.1 \pm 7.1 \mathrm{~L}$ compared with $11.8 \pm 6.0$ and $11.6 \pm 7.9 \mathrm{~L}$ under the same treatment at SA, respectively (Table 4).
Annual leachate nutrient flux. Many researchers consider that leachate nutrient flux, rather than concentrations, can give a better indication of nutrient losses from urban landscapes to ground or surface waters. Using univariate ANOVA with our two factors, we found that landscape species only had a significant effect on leachate orthophosphate-P flux (Table 3). However, irrigation water chemistry had a significant effect on all fluxes and the DOC:DON ratio (Table 3 ). The only significant interaction between irrigation water chemistry and landscape species was for orthophosphate-P flux (Table 3). Nitrate-N, ammonium-N, and DON fluxes were significantly higher at CS for the native and st. augustinegrass plant treatments relative to native and st. augustinegrass fluxes at SA (Fig. 2). Vegetative treatment had no significant effect on DON or bicarbonate flux within each site. The bicarbonate flux differences by irrigation were only significant in the st. augustinegrass treatment where the flux was larger in
CS relative to SA. DOC flux was significantly higher at CS compared with SA under the st. augustinegrass plant treatment (Fig. 2). SA had significantly higher orthophosphate-P flux under the tree + st. augustinegrass and tree plant treatments (Fig. 3). The orthophosphate-P flux for the tree treatment was larger than all other treatments except the tree + st. augustinegrass treatment (Fig. 3). Vegetation treatments had no effect on orthophosphate-P flux in CS. The DON:TDN ratio in this study ranged from 0.12 to 0.17 at SA and from 0.10 to 0.79 in CS.

Relationships between nutrient fluxes. Flux of DOC was significantly related to bicarbonate flux at $\mathrm{CS}\left(R^{2}=0.92 ; P<0.05 ; \mathrm{n}=6\right.$ treatments) but not at SA $\left(R^{2}=0.76 ; P=0.05\right.$; $\mathrm{n}=5$ treatments; Fig. 4). Dissolved organic N, typically strongly and significantly related to DOC in undisturbed ecosystems, was also related at $\mathrm{CS}\left(R^{2}=0.36 ; P<0.05 ; \mathrm{n}=15\right.$ plots $)$ and SA $\left(R^{2}=0.55 ; P<0.01 ; \mathrm{n}=15\right.$ plots $)$. There were no other significant relationships between fluxes at either CS or SA.

Table 3. Results of univariate analysis of variance with two factors, irrigation and plant species, and the interaction between irrigation water chemistry and plant species on leachate concentrations and fluxes. ${ }^{\mathrm{z}}$

\begin{tabular}{|c|c|c|c|c|c|c|c|c|c|c|c|c|}
\hline \multirow[b]{2}{*}{ Concentrations } & \multirow{2}{*}{$\begin{array}{l}\text { Leachate } \\
\left(\mathrm{L} \cdot \mathrm{m}^{-2}\right)\end{array}$} & \multirow[b]{2}{*}{$\mathrm{pH}$} & \multirow{2}{*}{$\begin{array}{c}\mathrm{EC} \\
\left(\mathrm{S} \cdot \mathrm{m}^{-1}\right)\end{array}$} & DOC & DON & $\mathrm{NO}_{3}{ }^{-}-\mathrm{N}$ & $\mathrm{NH}_{4}^{+}-\mathrm{N}$ & $\mathrm{PO}_{4}{ }^{3-}-\mathrm{P}$ & $\mathrm{HCO}_{3}^{-}$ & TDN & \multirow[b]{2}{*}{$\mathrm{DOC}: \mathrm{DON}$} & \multirow[b]{2}{*}{ DON:TDN } \\
\hline & & & & \multicolumn{7}{|c|}{ - } & & \\
\hline Irrigation & $<0.001$ & $<0.001$ & $<\mathbf{0 . 0 0 1}$ & 0.22 & 0.04 & 0.01 & 0.46 & $<0.001$ & 0.55 & $<0.01$ & 0.77 & 0.26 \\
\hline Species & 0.10 & 0.02 & $<\mathbf{0 . 0 0 1}$ & 0.22 & 0.08 & 0.02 & 0.17 & $<\mathbf{0 . 0 1}$ & 0.06 & 0.03 & 0.21 & $<0.01$ \\
\hline Irrigation*species & $<\mathbf{0 . 0 5}$ & 0.11 & 0.08 & 0.01 & 0.27 & 0.03 & 0.99 & $<\mathbf{0 . 0 0 1}$ & 0.02 & 0.03 & 0.01 & 0.9 \\
\hline$R^{2}$ & 0.13 & 0.38 & 0.30 & 0.10 & 0.07 & 0.11 & 0.04 & 0.41 & 0.10 & 0.10 & 0.08 & 0.09 \\
\hline Adjusted $R^{2}$ & 0.09 & 0.35 & 0.26 & 0.06 & 0.03 & 0.07 & 0.01 & 0.39 & 0.05 & 0.06 & 0.04 & 0.05 \\
\hline Fluxes & \multicolumn{3}{|l|}{$\mathrm{L} / \mathrm{m}^{2} /$ year } & \multicolumn{9}{|c|}{ 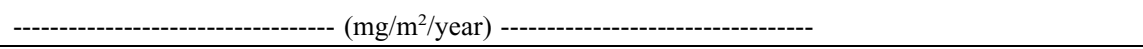 } \\
\hline Irrigation & $<0.01$ & - & - & 0.01 & $<0.001$ & $<0.001$ & 0.02 & $<\mathbf{0 . 0 0 1}$ & 0.02 & $<0.001$ & 0.03 & 0.64 \\
\hline Species & 0.27 & - & - & 0.37 & 0.60 & 0.85 & 0.23 & 0.03 & 0.17 & 0.82 & 0.34 & 0.26 \\
\hline Irrigation*species & 0.33 & - & - & 0.24 & 0.17 & 0.32 & 0.57 & 0.04 & 0.11 & 0.26 & 0.47 & 0.40 \\
\hline$R^{2}$ & 0.53 & - & - & 0.53 & 0.61 & 0.6 & 0.49 & 0.72 & 0.57 & 0.61 & 0.42 & 0.38 \\
\hline Adjusted $R^{2}$ & 0.29 & - & - & 0.29 & 0.42 & 0.4 & 0.4 & 0.58 & 0.35 & 0.42 & 0.13 & 0.07 \\
\hline
\end{tabular}

${ }^{\mathrm{z} B o l d}$ values show a significant effect from that factor at $\alpha<0.05$.

$\mathrm{EC}=$ electrical conductivity; $\mathrm{DOC}=$ dissolved organic carbon; $\mathrm{DON}=$ dissolved organic nitrogen; TDN $=$ total dissolved nitrogen.

Table 4. Annual mean leachate volume, pH, EC, annual nutrient concentrations, and bicarbonate concentrations in leachate collected from College Station and San Antonio.

\begin{tabular}{|c|c|c|c|c|c|c|c|c|c|c|c|}
\hline \multirow[b]{2}{*}{ Site } & \multirow[b]{2}{*}{ Vegetation } & \multirow{2}{*}{$\begin{array}{c}\text { No. } \\
\text { (Sample/plots) }\end{array}$} & \multirow{2}{*}{$\begin{array}{l}\text { Leachate } \\
\text { (L) }\end{array}$} & \multirow[b]{2}{*}{$\mathrm{pH}$} & \multirow{2}{*}{$\begin{array}{c}\mathrm{EC} \\
\left(\mathrm{S} \cdot \mathrm{m}^{-1}\right)\end{array}$} & DOC & DON & $\mathrm{NO}_{3}{ }^{-}-\mathrm{N}$ & $\mathrm{NH}_{4}{ }^{+}-\mathrm{N}$ & \multirow{2}{*}{$\begin{array}{l}\mathrm{PO}_{4}{ }^{3-}-\mathrm{P} \\
\left(\mu \mathrm{g} \cdot \mathrm{L}^{-1}\right)\end{array}$} & \multirow{2}{*}{$\begin{array}{l}\mathrm{HCO}_{3}^{-} \\
\left(\mathrm{mg} \cdot \mathrm{L}^{-1}\right)\end{array}$} \\
\hline & & & & & & \multicolumn{4}{|c|}{--1 } & & \\
\hline \multirow[t]{12}{*}{$\overline{\mathrm{CS}}$} & Tree & $25 / 3$ & 15.3 & x7.8 & 0.244 & ${ }^{\mathrm{x}} 11.0$ & ${ }^{\mathrm{ab}} 2.0$ & ${ }^{\mathrm{xab}} 16.7$ & 0.05 & $\times 4.5$ & 101 \\
\hline & & & $(8.8)$ & $(0.3)$ & $(0.043)$ & $(3.1)$ & $(1.1)$ & (4.2) & $(0.04)$ & $(0.9)$ & $(41)$ \\
\hline & Bermuda & $9 / 2$ & 18.5 & 8.0 & 0.265 & 16.0 & 0.9 & ${ }^{\mathrm{a}} 0.2$ & 0.00 & 10.9 & 132 \\
\hline & & & $(6.5)$ & $(0.1)$ & $(0.079)$ & $(1.8)$ & $(0.2)$ & $(0.0)$ & $(0.00)$ & $(8.9)$ & (1) \\
\hline & Tree + native & $10 / 2$ & $\mathrm{x} 19.1$ & $\times 7.8$ & 0.320 & 14.5 & b9.0 & c 44.3 & 0.03 & $\times 3.3$ & 99 \\
\hline & & & $(7.1)$ & $(0.2)$ & $(0.056)$ & $(1.1)$ & $(3.0)$ & $(16.8)$ & $(0.05)$ & $(0.9)$ & (26) \\
\hline & St. augustine & $35 / 3$ & 18.4 & x8.3 & ${ }^{x} 0.192$ & 14.5 & xab 3.5 & ${ }^{\mathrm{ab}} 16.0$ & 0.04 & $\times 3.7$ & 181 \\
\hline & & & $(7.3)$ & $(0.0)$ & $(0.045)$ & $(3.0)$ & $(0.9)$ & (2.0) & $(0.04)$ & $(0.4)$ & $(50)$ \\
\hline & Native & $16 / 2$ & ${ }^{\mathrm{x}} 17.9$ & 8.2 & 0.254 & 14.7 & ${ }^{\mathrm{ab}} 6.0$ & ${ }^{b c} 27.9$ & 0.04 & $\times 4.1$ & ${ }^{\mathrm{x}} 189$ \\
\hline & & & $(8.4)$ & $(0.3)$ & $(0.089)$ & $(1.4)$ & $(3.3)$ & (13.7) & $(0.04)$ & $(0.4)$ & (26) \\
\hline & Tree + st. augustine & $27 / 3$ & 14.9 & $\times 8.0$ & ${ }^{x} 0.223$ & 14.2 & $\mathrm{ab} 4.7$ & xabc 21.4 & 0.04 & $\times 2.5$ & 157 \\
\hline & & & $(5.1)$ & $(0.1)$ & $(0.008)$ & (1.4) & (3.1) & (6.6) & $(0.02)$ & $(0.6)$ & (6) \\
\hline \multirow[t]{10}{*}{ SA } & Tree & $27 / 3$ & 11.6 & y 8.7 & 0.216 & ${ }^{\mathrm{y}} 16.7$ & 3.9 & $\mathrm{y}_{27.4}$ & 0.08 & ${ }^{\mathrm{y}} 12.7$ & 155 \\
\hline & & & $(7.1)$ & $(0.2)$ & $(0.020)$ & (1.4) & (1.7) & (2.1) & $(0.06)$ & (3.8) & (15) \\
\hline & Tree + native & $16 / 3$ & ${ }^{\mathrm{y}} 11.6$ & ${ }^{\mathrm{y}} 8.6$ & 0.182 & 18.7 & 4.1 & $\mathrm{x} 13.8$ & 0.03 & $\mathrm{y}_{2} 28.5$ & 168 \\
\hline & & & $(7.9)$ & $(0.2)$ & $(0.107)$ & $(8.3)$ & (3.1) & (14.0) & $(0.04)$ & (12.5) & (17) \\
\hline & St. augustine & $18 / 3$ & 16.1 & ${ }^{\mathrm{y}} 8.8$ & ${ }^{\mathrm{y}} 0.105$ & 11.6 & ${ }^{\mathrm{y}} 1.2$ & 8.0 & 0.04 & ${ }^{\mathrm{y}} 13.4$ & 180 \\
\hline & & & $(6.4)$ & $(0.1)$ & $(0.046)$ & $(1.7)$ & $(0.9)$ & $(6.6)$ & $(0.04)$ & $(6.7)$ & $(42)$ \\
\hline & Native & $13 / 3$ & ${ }^{\mathrm{y}} 11.8$ & 8.5 & 0.195 & 12.5 & 3.0 & 16.6 & 0.05 & ${ }^{\mathrm{y}} 11.6$ & ya 106 \\
\hline & & & $(6.0)$ & $(0.2)$ & $(0.033)$ & $(2.1)$ & $(0.5)$ & $(2.0)$ & $(0.02)$ & $(0.6)$ & $(30)$ \\
\hline & Tree + st. augustine & $20 / 3$ & 16.8 & ${ }^{\mathrm{y}} 8.6$ & ${ }^{\mathrm{y}} 0.128$ & 14.1 & 2.0 & ${ }^{\text {y9. }}$ & 0.05 & ${ }^{\mathrm{y}} 17.8$ & 179 \\
\hline & & & $(5.1)$ & $(0.2)$ & $(0.046)$ & $(0.1)$ & $(1.2)$ & $(7.1)$ & $(0.01)$ & $(4.9)$ & $(74)$ \\
\hline
\end{tabular}

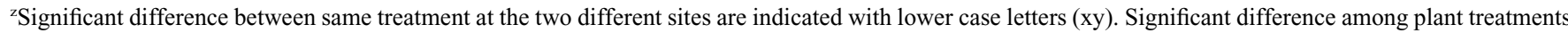
within each site are indicated with lowercase letters $(\mathrm{abc})$. Values in parenthesis are SD.

$\mathrm{EC}=$ electrical conductivity; DOC = dissolved organic carbon; DON = dissolved organic nitrogen; CS = College Station, TX; SA = San Antonio, TX. 


\section{Discussion}

Typically in an urban landscape with frequent irrigation, there is the tendency for solution to run off onto impervious surfaces and enter storm drains, which discharge directly to surface waters (Steele et al., 2010).
Solution leached from soils also has the potential to infiltrate to groundwater or move laterally to surface waters. There has been little research on DOC concentrations in soil solution leached from soil under turfgrass or runoff in mixed urban landscapes (e.g., Holgate et al., 2011; Schnell et al., 2010).

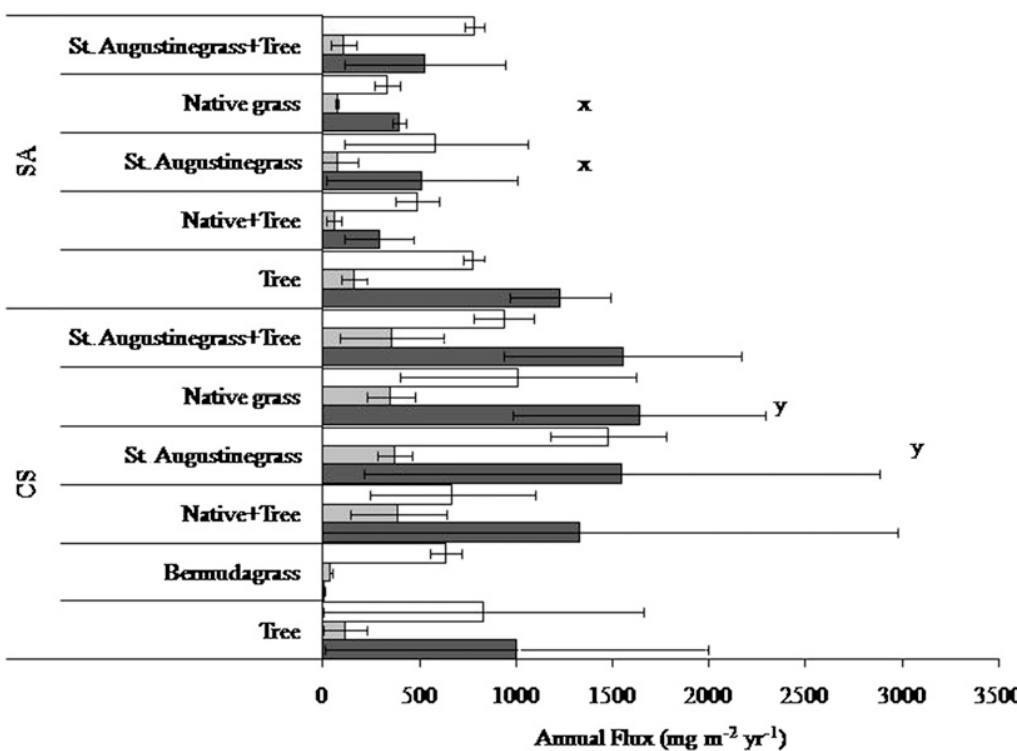

Fig. 2. Mean annual fluxes of nitrate-N, DON, and DOC at CS and SA. Significant difference $(P<0.05)$ between sites are indicated in lower case letters (xy). Error bars are SD. DON $=$ dissolved organic nitrogen; DOC $=$ dissolved organic carbon; $C S=$ College Station, TX; SA = San Antonio, TX.

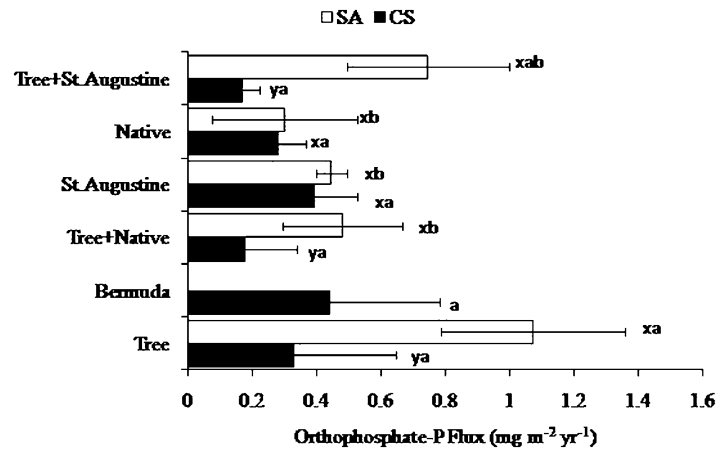

Fig. 3. Mean annual fluxes of orthophosphate-P. Significant difference $(P<0.05)$ between the same treatment at the two different sites are indicated with lower case letters (xy). Significant difference between plant treatments within each site are indicated with lowercase letters (ab). Error bars are SD.

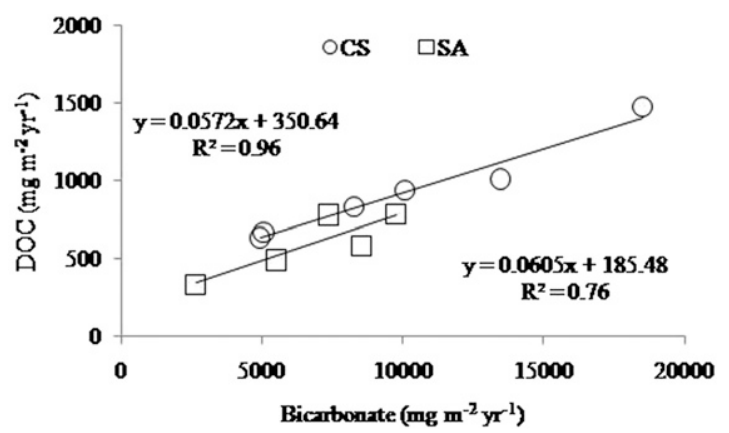

Fig. 4. Relationship between fluxes of DOC and bicarbonate at College Station and San Antonio. DOC $=$ dissolved organic carbon.
There has, however, been more research examining $\mathrm{N}$ and $\mathrm{P}$ leaching from turfgrasses (e.g., Erickson et al., 2001; Groffman et al., 2009; Schnell et al., 2010; Vietor et al., 2002) and mixed landscape species (e.g., Erickson et al., 1999, 2005, 2008).

Leachate volumes. Increased water volume at $\mathrm{CS}$ relative to $\mathrm{SA}$ for the native grass plots may have been the result of steady precipitation volumes at CS throughout the year compared with SA, which received several high-intensity rain events during the initial months of the study and much lower volumes during the latter part of the study year (Fig. 1). For example, for the periods May 2007 to Aug. 2007, Sept. to Dec. 2007, and Jan. 2008 to Apr. 2008, precipitation recorded at CS was 368,301 , and $302 \mathrm{~mm}$ compared with SA where values of 720,67 , and $83 \mathrm{~mm}$, respectively, were recorded. A $146-\mathrm{mm}$ event on 16 Aug. 2007 and 78-mm event on 18 June 2007 was recorded at SA, which may have led to runoff rather than infiltration thereby reducing actual input volumes at SA and resulting in lower leachate volumes. However, we would expect that under this scenario that all plant treatments would display lower leachate volumes at SA compared with CS and this was not the case. We do believe however that increased leachate volume under the native plots at CS was the result of reduced plant uptake. Examining the soil moisture data over the period of the study (Table 5), it was evident that water use in CS was significantly reduced relative to SA, particularly for the native + tree plots at CS for the whole period of the study (Table 5). For three of the four periods analyzed, water use was significantly reduced in the native grass and st. augustinegrass treatments at CS compared with SA (Table 5). Water use was only significantly different between CS and SA for the tree treatment during the summer and fall months where the trees at CS displayed significantly lower water use (Table 5). Because of reduced water use in CS relative to SA, we suggest that the use of high sodium bicarbonate water may have affected plant water uptake. High soil sodium generally reduces plant transpiration and biomass accumulation in landscape vegetation (Eom et al., 2007) found differential responses of six herbaceous perennials to soil sodium concentrations, transpiration, and reduced biomass.

Nitrogen and phosphorous. Work by Erickson et al. (2001, 2005) on turfgrass and mixed landscape amenity species showed that inorganic $\mathrm{N}$ and total $\mathrm{P}$ transport varied by plant treatment in studies on sand in South Florida in a long-term study where data reported represented 16 to 52 months after plant installation. They reported that $\mathrm{N}$ and $\mathrm{P}$ leaching was reduced from st. augustinegrass plots compared with mixed landscape plots and suggested that relatively longer establishment was needed for st. augustinegrass relative to mixed landscape species. We also found a plant treatment effect on nitrate and orthophosphate concentrations and orthophosphate-P flux among our two Texas sites. The tree treatment had higher ammonium flux than the native and tree + native treatments and orthophosphate-P 
Table 5. Average water use for each plant treatment as calculated by soil moisture sensors during the period of study. ${ }^{z}$

\begin{tabular}{|c|c|c|c|c|c|}
\hline & & $\begin{array}{c}\text { Mar. to } \\
\text { May } 2007\end{array}$ & $\begin{array}{c}\text { June to } \\
\text { Sept. } 2007\end{array}$ & $\begin{array}{c}\text { Oct. to } \\
\text { Nov. } 2007\end{array}$ & $\begin{array}{c}\text { Mar. to } \\
\text { May } 2008\end{array}$ \\
\hline & & \multicolumn{4}{|c|}{$(\mathrm{mm})$} \\
\hline$\overline{\mathrm{SA}}$ & Native +tree & ${ }^{\mathrm{a}} 1.98$ & a2.91 & a2.96 & ${ }^{\mathrm{a}} 1.48$ \\
\hline $\mathrm{CS}$ & Native + tree & ${ }^{\mathrm{b}} 1.08$ & b2.07 & b 1.60 & ${ }^{\mathrm{b}} 0.86$ \\
\hline SA & Native & ${ }^{\mathrm{a}} 1.64$ & 2.21 & a2.04 & ${ }^{\mathrm{a}} 1.35$ \\
\hline $\mathrm{CS}$ & Native & b 1.10 & 1.89 & ${ }^{\mathrm{b}} 1.11$ & b 0.73 \\
\hline SA & Tree & 0.96 & ${ }^{\mathrm{a}} 1.95$ & ${ }^{\mathrm{a}} 1.96$ & 1.08 \\
\hline $\mathrm{CS}$ & Tree & 0.44 & b 0.86 & b0.79 & 1.02 \\
\hline SA & St. augustinegrass & 1.37 & a 2.221 & ${ }^{\mathrm{a}} 1.703$ & 2.159 \\
\hline $\mathrm{CS}$ & St. augustinegrass & 1.29 & b 1.096 & b 1.128 & b0.957 \\
\hline SA & St. augustinegrass + tree & 1.65 & 2.04 & ${ }^{\mathrm{a}} 1.66$ & a) 2.36 \\
\hline $\mathrm{CS}$ & St. augustinegrass + tree & 1.37 & 1.52 & ${ }^{\mathrm{b}} 1.02$ & ${ }^{\mathrm{b}} 0.83$ \\
\hline
\end{tabular}

${ }^{z}$ Values in parentheses are SD. Differences in lowercase superscript letters indicate significant difference in water use between SA and CS for each plant treatment.

$\mathrm{SA}=$ San Antonio, TX; CS = College Station, TX

flux was higher in the tree-only treatment relative to the st. augustinegrass, native, and tree + native treatments. This suggests that the dense network of grass roots may have captured more nutrients than the root system of the tree alone, thus reducing leachate $\mathrm{N}$ and $\mathrm{P}$. Alternatively, $\mathrm{N}$ and $\mathrm{P}$ requirements for the tree plant treatment may have been much less than that of the grass plant treatments. Unlike the Erickson et al. (2005) study that had differing fertilization regimes for st. augustinegrass and mixed species treatments, we applied the same fertilizer at the same frequency and rate to all of our plant treatments. Although our study differed in terms of time of plant establishment and fertilization, both studies found reduced $\mathrm{N}$ and $\mathrm{P}$ leaching from st. augustinegrass.

Vegetation cannot use organic $\mathrm{N}$ with the exception of some amino acids (Lipson and Nasholm, 2001; Schimel and Chapin, 1996); therefore, the organic $\mathrm{N}$ undergoes ammonification, which is then available to plants. Ammonium binds tightly to most soils and does not typically leach into groundwater (Gardiner and Miller, 2008). This was well supported by our study in which no significant differences in $\mathrm{NH}_{4}-\mathrm{N}$ concentrations were observed. Very few studies have examined DON leaching from soil under turfgrass, and most that have applied compost or manure. For example, Cheng et al. (2008) quantified soil solution DON in 28 home lawns comprised of several cool-season turfgrasses and presumably several soil series in two Ohio counties. Over three sampling periods, they reported that DON concentrations ranged from 0 to $29.34 \mathrm{mg} \cdot \mathrm{L}^{-1}$. This compares well with our study in which individual DON concentrations ranged from 0 to $37.16 \mathrm{mg} \cdot \mathrm{L}^{-1}$.

The ratio of DON:TDN is typically greater than 0.75 in undisturbed ecosystems, which generally indicates relatively tight cycling of N (Aitkenhead-Peterson et al., 2011a). Why DON:TDN values were so low at SA (DON:TDN $=0.12$ to 0.17 ) relative to values at $\mathrm{CS}$ (DON:TDN $=0.10$ to 0.79 ) is unknown, but typically low DON:TDN values suggest exposure to sewage effluent (AitkenheadPeterson et al., 2009), which is consistent with the position of the SA plots near a wastewater treatment facility. DON:TDN ratios of between 0.22 and 0.35 were reported in unplanted green roof growth medium and a failing $S$. kamtschaticum species, which was suggested to be indicative of a soil/plant system unable to use $\mathrm{N}$ (Aitkenhead-Peterson et al., 2011a). The high sodium irrigation water at CS affected foliar health as determined by st. augustinegrass biomass production of $41.9 \mathrm{Mg} \cdot \mathrm{ha}^{-1}$ at SA and $25.5 \mathrm{Mg} \cdot \mathrm{ha}^{-1}$ at CS (Pannkuk et al., 2010).

Dissolved organic N, a subset of dissolved organic matter that includes DOC, is often strongly and significantly related to DOC in undisturbed ecosystems (Aitkenhead-Peterson et al., 2003). In our study, we found that DON fluxes were significantly related to DOC fluxes, but the variance in DON explained by DOC was much higher at SA than at CS. This suggests that there was some decoupling of DON and DOC at CS, which may have been induced by irrigation with sodic water.

Carbon. The importance of examining leachate DOC is to quantify losses of soil carbon that might otherwise contribute to soil carbon sequestration. Furthermore, humic acids leaching to groundwater aquifers have the potential to form trihalomethanes if the groundwater is chlorinated for potable use (Siddiqui et al., 1997). The concentration of DOC in a soil solution collected by zero tension and tension lysimeters varies considerably and is dependent on land use (AitkenheadPeterson et al., 2003). Some of our individual samples yielded DOC concentrations as high as $327.25 \mathrm{mg} \cdot \mathrm{L}^{-1}$, which were comparable to water-extractable DOC concentrations of $326 \mathrm{mg} \cdot \mathrm{L}^{-1}$ reported by Provin et al. (2008). Our mean annual concentrations ranged from 11 to $17 \mathrm{mg} \mathrm{C} \cdot \mathrm{L}^{-1}$, which is typical for DOC concentration in mineral soil solution under a wide range of land uses, including turfgrass (Aitkenhead-Peterson et al., 2003; Schnell et al., 2010). Runoff concentrations from bermudagrass plots with and without composted biosolids were reported by Schnell et al. (2010), who found that, over seven rain events, the mean DOC concentration in runoff was $8.6 \pm 3.2 \mathrm{mg} \cdot \mathrm{L}^{-1}$ from plots without biosolids and $35.9 \pm 15.5 \mathrm{mg} \cdot \mathrm{L}^{-1}$ from plots with biosolids addition. Our DOC concentrations at CS under bermudagrass were slightly higher than those reported by Schnell et al.
(2010) but within the same order of magnitude. Fluxes of DOC ranged from 636 to 1474 $\mathrm{mg} / \mathrm{m}^{2} /$ year at CS from bermudagrass and st. augustinegrass, respectively, and from 333 to $785 \mathrm{mg} / \mathrm{m}^{2} /$ year from native grasses and st. augustinegrass + tree, respectively, at SA. Our expectation that irrigation water higher in sodium relative to calcium would increase DOC fluxes from all vegetation types was not met because only the st. augustinegrass treatment had significantly higher DOC flux at $\mathrm{CS}$, which could be attributed to irrigation water.

Ninety-two percent of the variance in DOC flux was explained by bicarbonate flux at CS and although a similar relationship occurred at SA, it was not as strong nor was it significant. The relationship between DOC and bicarbonate may provide some clues to potential mechanisms of leaching of soil DOC from urban landscapes based on alkalinity levels in irrigation water sources. One hypothesis is that with neutral $\mathrm{pH}$ and high alkalinity, both humic and fulvic acids, are soluble in solution (Stevenson, 1994), whereas in undisturbed ecosystems with lower $\mathrm{pH}$ and alkalinity, fulvic acids dominate bulk DOC. A relationship between DOC and bicarbonate appears to occur in neutral $\mathrm{pH}$, humin-dominated aquatic systems. For example, $86 \%$ of the variance in DOC was explained by bicarbonate in the four subbasins of the Mississippi River (Dubois et al., 2010). A second hypothesis is that percolating irrigation water containing significantly high bicarbonate concentrations may compete with indigenous absorbed DOC on mineral soil surfaces; research is needed to test this hypothesis.

Plant selection. In agricultural systems, farmers typically select crops to grow based on crop tolerance of local soil conditions and irrigation water chemistry. In ornamental horticulture, plants are typically selected for aesthetic and use purposes based on cold-hardiness zoning. Our study illustrated that landscape species selection, within reason, seems to have a little to no effect on nutrient leaching losses (determined as fluxes) and that landscape management practices such as type of water input and fertilization practices seem to be much more important.

Limitations to the study. The results of this study are for the first year after establishment of landscape plants after a 4-month equilibrium period and results may be very different for horticultural plants that have been established for a longer time period.

One reason why significant differences did not occur in leachate chemistry among vegetative species at each site may have been the depth of the lysimeter. Leachate was collected from the saturated flow zone contained within the gravel layer rather than from the unsaturated flow zone within the soil horizon. With collections of leachate every 2 to 4 weeks, the solution may have been in reducing rather than oxidizing conditions, which may have confounded any differences in $\mathrm{N}$ we should have observed among species at each site. A solution to this would be to install zerotension or ceramic cup tension lysimeters in the 
soil profile or collect leachate after each irrigation and rain event and filter and freeze until analysis.

Orthophosphate-P concentration and flux and DON:TDN ratio differences between sites may have been confounded by the presence of the SA sewage treatment facility 400 to 500 $\mathrm{m}$ from the SA lysimeters. At this sewage treatment facility, wind-row piles of solid sludge were composted in full sunlight. Particulate matter from these piles may have become airborne and settled on the experiment site. The single tree, tree + native, tree + st. augustinegrass and native treatments had significantly higher orthophosphate-P fluxes at SA relative to those treatments in CS, which may be the result of their height and particle-scavenging ability.

Conclusions. Irrigation water chemistry had a larger impact on nutrient leaching from urban landscapes than the impact from the type of horticultural plant. Plants did, however, have an effect on concentrations of nitrate-N orthophosphate-P; on $\mathrm{pH}, \mathrm{EC}$, and the DON:TDN ratio; and on fluxes of orthophosphate-P among the two sites. We also observed irrigation and plant species interactions for leachate concentrations of DOC, nitrate-N, orthophosphate-P, and bicarbonate and the DOC:DON ratio. Much more research on the impact of irrigation water chemistry on nutrient leaching and runoff in planted urban landscapes species is needed, particularly the interactions between irrigation water chemistry and horticultural plant species.

\section{Literature Cited}

Aitkenhead-Peterson, J.A., J.E. Alexander, and T.A. Clair. 2005. Dissolved organic carbon and dissolved organic nitrogen export from forested watersheds in Nova Scotia: Identifying controlling factors. Global Biogeochem. Cycles 19:GB4016.

Aitkenhead-Peterson, J.A., B. Dvorak, A. Volder, and N. Stanley. 2011a. Species effect on water extractable and leachate chemistry during establishment of a green roof. Urban Ecosyst. (in press).

Aitkenhead-Peterson, J.A., N. Nahar, C. Harclerode, and N. Stanley. 2011b. Chemistry of urban and rural watersheds in central Texas. Urban Ecosyst. (in press).

Aitkenhead-Peterson, J.A., W.H. McDowell, and J.C. Neff. 2003. Sources, production, and regulation of allochthonous dissolved organic matter to surface waters. In: Findlay, S.E.G. and R.L. Sinsabaugh (eds.). Aquatic ecosystems: Interactivity of dissolved organic matter. Academic Press, San Diego, CA.

Aitkenhead-Peterson, J.A., M.K. Steele, N. Nahar, and K. Santhy. 2009. Dissolved organic carbon and nitrogen in urban and rural watersheds of south-central Texas: Land use and land management influences. Biogeochemistry 96:119-129.

Beard, J.B. and R.L. Green. 1994. The role of turfgrasses in environmental protection and their benefits to humans. J. Environ. Qual. 23: 452-460.
Cheng, Z., D.S. Richmond, S.O. Salminen, and P.S. Grewal. 2008. Ecology of urban lawns under three common management programs. Urban Ecosyst. 11:177-195.

City of Albuquerque. 2006. Water conservation home. 27 June 2009. <http://www.cabq.gov/ waterconservation/index.html $>$.

Dubois, K.D., D. Lee, and J. Veizwe. 2010. Isotopic constraints on alkalinity, dissolved organic carbon, and atmospheric carbon dioxide fluxes in the Mississippi River. J. Geophys. Res. 115:G02018.

Eom, S.H., T.L. Setter, A. DiTommaso, and L.A. Weston. 2007. Differential growth response to salt stress among selected ornamentals. J. of Plant Nutrition 30:1109-1126.

Erickson, J.E., J.L. Cisar, G.H. Snyder, D.M. Park, and K.E. Williams. 2008. Does a mixed-species landscape reduce inorganic-nitrogen leaching compared to a conventional st. augustinegrass lawn? Crop Sci. 48:1586-1594.

Erickson, J.E., J.L. Cisar, G.H. Snyder, and J.C. Volin. 2005. Phosphorus and potassium leaching under contrasting residential landscape models established on a sandy soil. Crop Sci. 45:546-552.

Erickson, J.E., J.L. Cisar, J.C. Volin, and G.H. Snyder. 2001. Comparing nitrogen runoff and leaching between newly established st. augustinegrass turf and an alternative residential landscape. Crop Sci. 41:1889-1895.

Erickson, J.E., J.C. Volin, J.L. Cisar, and G.H. Snyder. 1999. A facility for documenting the effect of urban landscape type on fertilizer nitrogen runoff. Proc. Fla. State Hort. Soc. 112 : 266-269.

FAO. 1998. Irrigation and drainage papers 56. The Food and Agriculture Organization web site. 20 June 2006. <http://www.fao.org/docrep/X0490E/ x0490e06.htm>.

Faulkner, H., V. Edmonds-Brown, and A. Green. 2000. Problems of quality designed in diffusely polluted urban streams - The case of Pymme's Brook, North London. Environ. Pollut. 109:91107.

Gardiner, D.T. and R.W. Miller. 2008. Soils in our environment. Prentice Hall, Upper Saddle River, NJ.

Garner, A., J. Stevely, H. Smith, M. Hoppe, T. Floyd, and P. Hinchcliff. 1996. A guide to environmentally friendly landscaping. Florida Yards and Neighborhoods Handbook. Inst. of Food and Agric. Sci. Bull. 295. Univ. of Florida, Gainesville, FL.

Groffman, P.M., C.O. Williams, R.V. Pouyat, L.E. Band, and I.D. Yesilonis. 2009. Nitrate leaching and nitrous oxide flux in urban forests and grasslands. J. Environ. Qual. 38:1848-1860.

Hipp, B.S., S. Alexander, and T. Knowles. 1993. Use of resource efficient plants to reduce nitrogen, phosphorus, and pesticide runoff in residential and commercial landscapes. Water Sci. Technol. 28:205-213.

Holgate, L.C., J.A. Aitkenhead-Peterson, and T.J. Gentry. 2011. Irrigation water chemistry: Impact on microbial community composition and biogeochemical leaching under Lolium perenne (L.). ISRN Ecol. 797910.
Jenny, H. 1941. Factors of soil formation. a system of quantitative pedology. McGraw Hill Book Company, New York, NY.

Jiang, Z., J.T. Bushoven, H.J. Ford, and C.D. Sawyer. 2000. Mobility of soil nitrogen and microbial responses following the sudden death of established turf. J. Environ. Qual. 29:16251631.

Lipson, D. and T. Nasholm. 2001. The unexpected versatility of plants: Organic nitrogen use and availability in terrestrial ecosystems. Oecologia 128:305-316.

McConnell, J.B. 1980. Impact of urban storm runoff on stream quality near Atlanta, Georgia. EPA600/2-80-094. U.S. EPA, Washington, DC.

Paerl, H.W. 2009. Controlling eutrophication along the freshwater-marine continuum: Dual nutrient $(\mathrm{N}$ and $\mathrm{P})$ reductions are essential. Estuaries Coasts 32:593-601.

Pannkuk, T.R., R.H. White, K. Steinke, J.A. Aitkenhead-Peterson, D.R. Chalmers, and J.C. Thomas. 2010. Landscape coefficients for single- and mixed-species landscapes. HortScience 45:1529-1533.

Perakis, S.S. and L.O. Hedin. 2007. State factor relationships of dissolved organic carbon and nitrogen losses from unpolluted temperate forest watersheds. J. Geophys Res-Biogeosciences 112:G02010.

Provin, T.L., A.L. Wright, F.M. Hons, and D.A. Zuberer. 2008. Seasonal dynamics of soil micronutrients in compost-amended bermudagrass turf. Bioresour. Technol. 99:2672-2679.

Sacamano, C.M. and W.D. Jones. 1975. Native trees and shrubs for landscape use in the desert southwest. Univ. Arizona Coop. Ext. Serv. Bull A-82. Univ. of Arizona, Tucson, AZ.

SAS Institute. 2003. SAS user's guide: Statistics, SAS system. Version 8. SAS Inst., Cary, NC.

Schimel, J.P. and F.S. Chapin. 1996. Tundra plant uptake of amino acid and $\mathrm{NH}_{4}{ }^{+}$nitrogen in situ: Plants compete well for amino acid N. Ecology 77:2142-2147.

Schnell, R.W., D.M. Vietor, C.L. Munster, R.H. White, and T.L. Provin. 2010. Effect of turfgrass establishment practices and composted biosolids on water quality. J. Environ. Qual. 39:697-705.

Siddiqui, M.S., G.L. Amy, and B.D. Murphy. 1997. Ozone enhanced removal of natural organic matter from drinking water sources. Water Res. 31:3098-3106.

Steele, M.K., W.H. McDowell, and J.A. AitkenheadPeterson. 2010. Chemistry of urban, suburban and rural surface waters. In: AitkenheadPeterson, J.A. and A. Volder (eds.). Urban ecosystem ecology agronomy monograph 55 . ASA, CSSA, SSSA, Madison WI.

Stevenson, F. 1994. Humus chemistry: Genesis, composition, reactions. John Wiley \& Sons, New York, NY.

Vickers, A. 2001. Water use and conservation. WaterPlow Press, Amherst, MA.

Vietor, D.M., E.N. Griffith, R.H. White, T.L. Provin, J.P. Muir, and J.C. Read. 2002. Export of manure phosphorus and nitrogen in turfgrass sod. J. Environ. Qual. 31:1731-1738.

Xeriscape Colorado. 2005. What is xeriscape? Colorado WaterWise Council, Denver, CO. 5 Oct. 2009. <http://www.xeriscape.org/index.html $>$. 